\title{
PERANAN BADAN PERMUSYAWARATAN DESA (BPD) DALAM MENAMPUNG DAN MENYALURKAN ASPIRASI UNTUK MELESTARIKAN BUDAYA MASYARAKAT DI DESA \\ SOLAM RAYA KECAMATAN SUNGAI TEBELIAN KABUPATEN SINTANG
}

\author{
Antonius Erwandi \\ Fakultas Ilmu Sosial Dan Ilmu Politik Universitas Kapuas Sintang \\ Jalan Oevang Oeray 92 Sintang \\ Email : erwandi.unka@gmail.com
}

\begin{abstract}
Abstrac
BPD is representative of the community that is in the village government system so that it has a role in absorbing and channeling the aspirations of the community in various aspects including in developing the socio-cultural goals so that community culture can be preserved in social life through the involvement of village government.
\end{abstract}

Keywords: Village Consultative Body, Aspiration, Culture

\section{Abstrak}

BPD merupakan perwakilan masyarakat yang berada pada sistem pemerintahan desa sehingga memiliki peran dalam menyerap dan menyalurkan aspirasi masyarakat dalam berbagai aspek termasuk dalam mengembangkan sosial budaya tujuannya agar kebudayaan masyarakat dapat terpelihara dalam kehidupan sosial melalui keterlibatan pemerintah desa.

Kata Kunci : Badan Permusyawaratan Desa, Aspirasi, Budaya.

\section{Latar Belakang}

Peran Badan Permusyawaratan Desa atau BPD sebagai lembaga pemerintahan desa memiliki arti penting dalam melestarikan kebudayaan di dalam masyarakat mengingat BPD sebagai lembaga yang mewakili masyarakat desa di lembaga pemerintahan. Amanat Undang-Undang Nomor 6 tahun 2014 Tentang Desa khususnya Bab I Pasal 1 menyebutkan bahwa Badan Permusyawaratan Desa atau yang disebut dengan nama lain adalah lembaga yang melaksanakan fungsi pemerintahan yang anggotanya merupakan wakil dari penduduk desa berdasarkan keterwakilan wilayah dan ditetapkan secara demokratis. Selanjutnya dalam UndangUndang Nomor 6 tahun 2014 Tentang Desa khususnya pasal 63 poin e bahwa BPD wajib menghormati nilai sosial budaya dan adat istiadat masyarakat Desa. salah satu wujud dari menghormati adat istiadat masyarakat desa yaitu dengan membuat peraturan desa 
tentang pelestarian nilai-nilai adat kebudayaan masyarakat setempat.

Sesuai dengan amanat UndangUndang nomor 6 Tahun 2014 Tentang Desa, BPD sebagai salah satu lembaga perwakilan masyarakat ditingkat desa harus dapat menampung aspirasi masyarakat yang kemudian memberikan suatu kepastian agar kebudayaan yang terdapat di dalam masyarakat tersebut dapat terus terjaga dan di lestarikan sebagai bentuk identitas bagi masyarakatnya. Pembangunan kebudayaan masyarakat di desa merupakan salah satu landasan dari terbentuknya suatu masyarakat yang bermartabat, demikian juga jika pembangunan budaya kurang mendapat perhatian akan berdampak kurang baik dalam membangun karakteristik bangsa, mengingat bangsa Indonesia terdiri dari berbagai macam suku dan budaya yang harus dihargai dan dihormati oleh semua elemen dalam pembangunan.

Pentingnya budaya tidak saja sebagai potensi yang dapat dikembangkan akan tetapi jika dilihat dari sejarahnya, kebudayaan merupakan salah satu unsur yang dapat menciptakan berbagai nilai-nilai pemersatu masyarakat. keberadaan kebudayaan masyarakat yang masih ada hingga saat ini seperti kebudayaan tari, seni budaya kuda lumping, wayang juga menjadi salah satu kegiatan yang positif yang dapat diwariskan kepada generasi berikutnya.

Permasalahan yang dihadapi dalam mempertahankan kebudayaan yaitu semakin luasnyaperkembanganbudaya-budayamodern dan budaya asing yang dapat melemahkan kebudayaan lokal, Sedangkan di daerah solam raya terdapat adanya kebudayaan masyarakat seperti kuda lumping dan tarian adat dayak yang belum dijadikan sebagai potensi di Desa Solam Raya sehingga diperlukan suatu strategi yang dapat menampung kehendak masyarakat setempat.

\section{Pembahasan}

\section{A. Deskripsi wilayah Penelitian}

Deskripsi Wilayah Penelitian

Desa Solam Raya merupakan salah satu desa yang terletak di wilayah Kecamatan Sungai Tebelian Kabupaten Sintang dengan Luas wilayah 2.160 Ha. Sedangkan secara adminisratif batas wilayah Desa Solam Raya yaitu :

- Sebelah Utara berbatasan dengan Desa Perembang

- - Sebelah Timur berbatasan dengan Desa Bonet Lama

- - Sebelah Selatan berbatasan dengan Desa Rarai

- - Sebelah Barat berbatsan dengan Desa Kenyabur Baru, Desa Riam Kijang Kecamatan Tempunak.

Berdasarkan tata letak batas administratif tersebut dapat dijelaskan bahwa 
letak desa Solam Raya berada di pedalaman atau tidak terletak di pinggiran jalan utama menuju ke Kabupaten Melawi, hal ini cukup menguntungkan karena letak desa Solam Raya berbatasan dengan Kecamatan Tempunak dimana akses jalan menuju kecamatan Tempunak dan juga menuju ke keamatan Sungai Tebelian dapat dilalui dengen kendaraan roda empat. Selain itu keberadaan desa-desa yang berbatasan dengan Desa Solam Raya umumnya masyarakat transmigrasi yang sudah sejak lama di tempatkan di daerah sekitar Kecamatan Sungai Tebelian sehingga akan lebih beragam kebudayaan yang ada di desa tersebut.

Jumlah Rumah Tangga masyarakat Desa Solam Raya berdasarkan data tahun 2014 yaitu 645 kepala keluarga sedangkan dari aspek mata pencaharian masyarakat desa Solam Raya umumnya petani dan pekebun hal ini terlihat dari luas perkebunan yaitu 1600 Ha dari luas wilayah Desa Solam Raya. Areal perkebunan masyarakat yang semakin meningkat berdampak pada perpindahan penduduk sehingga penduduk di Kecamatan sungai Tebelian umumnya berasal dari luar Kalimantan hal ini juga dipengaruhi oleh program transmigrasi pada tahun 80 -an yang sudah ada di Kecamatan Sungai tebelian. namun demikian tingkat keharmonisan masyarakat yang multikultur tersebut sangat tinggi dan saling mendukung dalam melaksanakan kebudayaan masing-masing.

\section{B. Tata Cara Menyerap Aspirasi Masyarakat}

Berdasarkan hasil wawancara dengan

Kepala Desa Solam Raya Kecamatan Sungai Tebelian diperoleh informasi yaitu berdasarkan tugas pokok dan fungsi BPD selama ini sistem dan tata cara penyaluran aspirasi dari masyarakat yaitu melalui rapatrapat BPD dengan para tokoh masyarakat yang diundang sesuai dengan rencana waktu pembahasan Musrenbangdes. peran tokoh masyarakat tentunya sudah mewakili apa yang menjadi keinginan masyarakat dan untuk mengetahui keinginan masyarakat para tokoh masyarakat biasanya lebih memahami secara menyeluruh.

Lebih lanjut hasil wawancara dengan Kepala Desa Solam Raya menuturkan bahwa peran BPD sudah baik dalam menyampaikan aspirasi-aspirasi masyarakat kepada forum rapat musrenbang yang disampaikan selanjutnya oleh pemerintah desa kepada pemerintah kecamatan. Sedangkan aspirasi yang diperlukan untuk meningkatkan berbagai potensi yang ada di masyarakat juga disampaikan kepada pemerintah desa sehingga kebijakan pemerintah desa tidak harus menunggu hasil musrenbang jika memungkinkan untuk diambil kebijakan 
di tingkat desa. Demikian juga dengan pelestarian adat budaya di masyarakat yang dapat memberikan dampak positif bagi masyarakat.

Berikutnya hasil wawancara dengan Ketua BPD Desa Solam Raya Kecamatan Sungai Tebelian disampaikan selama ini BPD sudah melaksanakan perannya dalam menampung dan menyalurkan aspirasi masyarakat di desa Solam Raya dalam berbagai bentuk baik secara tertulis maupun yang disampaikan secara lisan dalam hasil rapat koordinasi BPD dengan masyarakat. Berkaitan dengan tatacara penyampaian aspirasi juga sudah berlangsung sesuai dengan iklim demokrasi dimana pola-pola aspirasi yang disampaikan berkenaan dengan aspek-aspek pembangunan yang belum maksimal dilakukan oleh pemerintah desa. Selain itu aspirasi dalam bentuk budaya yaitu melestarikan adat budaya masyarakat juga merupakan aspirasi yang sudah dilaksanakan oleh pemerintah desa dimana pemerintah desa memberikan ruang dan kebebasan bagi setiap suku yang ada untuk dapat melestarikan adat budaya demi keberlangsungan pembangunan daerah.

Lebihlanjut dituturkan oleh Ketua BPD pada dasarnya masyarakat sudah memahami berbagai tatacara dalam menyampaikan aspirasinya, selain itu juga masyarakat sangat menhormati peran BPD yang dalam era desentralisasi ini sangat membantu masyarakat dalam menjembatani keinginan masyarakat dengan pemerintah. Bahkan dalam proses-proses tatacara menjaring aspirasi oleh BPD sangat kompleks yang di kemukakan tidaksaja dalam hal pembangunan namun dalam hal permasalahan-permasalahan dalam masyarakat juga sering disampaikan kepada BPD. hal itu membuktikan bahwa antara BPD dan masyarakat terdapat suatu koordinasi yang sangat baik sehingga pola-pola perencanaan pembangunan juga akan semakin terarah.

Berdasarkan hasil-hasil wawancara yang telah diperoleh dari Ketua BPD Solam Raya dapat dideskripsikan yaitu kondisi demokrasi desa yang sudah diamanatkan oleh Undang-Ukat untuk menyampaikan Undang-Undang nomor 32 tahun 2012 tentang otonomi daerah dan Undang-Undang tentang desa merupakan bentuk kebijakan yang dapat diterima oleh masyarakat dan dimanfaatkan dengan baik oleh masyarakat dalam, menyampaikan aspirasinya sehingga akan sangat memudahkan bagi pemerintah memberikan arah pembangunan. Secara normatif pemerintah desa dan BPD dalam mejalankan kebijakan juga sudah mengacu pada proses-proses dan tatacara yang dapat dipahami oleh masyarakat. kebersamaan masyarakat dan pemerintah merupakan salah 
satu modal dalam menjalankan pembangunan. Apapun yang diharapkan oleh kebijakan tentunya akan terus berlangsung seiring dengan waktu serta kondisi yang sesuai bagi iklim demokrasi di tingkat desa dan dengan demikian kebudayaan masyarakat sebagai bagian dari hasil cipta dan karya juga akan dapat dijalankan dengan tidak bertentangan dengan ketentuan yang berlaku.

Berikutnya hasil wawancara dengan Anggota BPD Desa Solam Raya Kecamatan Sungai Tebelian dikatakan bahwa untuk melaksanakan kerja pelayanan kepada masyarakat terutama dalam melakukan peran sebagai perwakilan masyarakat di tingkat desa anggota BPD diberikan kesempatan untuk seluas-luasnya menjaring apasaja yang menjadi keinginan masyarakat. Sistem dan tatacara dalam menampung aspirasi sudah dipahami oleh anggota BPD yang mewakili dari setiap dusun yang ada. Tatacara penyampaian aspirasi sudah disosialisasikan kepada masyarakat dan untuk saat ini sudah berjalan dengan benar oleh karena itu dalam melestarikan budaya khususnya kesenian yang berasal dari luar daerah juga sudah dilakukan oleh masyarakat, demikian juga dengan masyarakat asli daerah yang diberi kebebasan dalam mengapreseasikan kebudayaan bersama dalam berbagai momen baik secara keluarga maupun kelompok. Kondisi ini terus dijaga demi terciptanya suatu kondisi yang aman dan juga harmonis bagi semua warga masyarakat. Selanjutnya menurut anggota BPD diperoleh informasi bahwa peran BPD dalam menampung dan menyalurkan aspirasi masyarakat tidak terbatas waktu artinya kapan saja masyarakat dapat menyampaikan aspirasinya kepada anggota BPD, selain itu BPD juga sudah menjadwalkan rapat dengan masyarakat sebelum musrenbang desa dilakukan namun terbatasnya waktu maka diperlukan tatacara diluar rapat-rapat khusus masyarakat dengan BPD. Tatacara tentunya tidak harus bersifat formal karena kebiasaan dalam masyarakat umumnya lebih terbuka jika sistem penyampaian aspirasi disampaikan pada anggota BPD pada saat yang tidak ditentukan seperti pada saat rapat. Oleh karenya tatacara demikian lebih efektif dan tidak bertentangan dengan ketentuan tetapi yang disampaikan jelas merupakan kepentingan bersama bagi masyarakat luas.

Berangkat dari hasil wawancara yang terhimpun dari anggota BPD Solam Raya dapat dijelaskan bahwa pelaksanaan penyampaian aspirasi oleh masyarakat umumnya tidaksaja pada saat rapat BPD dengan masyarakat tetapi juga dapat dilakukan secara bebas tanpa adanya ketentuan waktu. Hal ini dikarenakan pada saat rapat waktunya sangat terbatas sehingga belum dapat menampung hal-hal 
yang akan disampaikan oleh masyarakat.

Berkenaan dengan tatacara penyampaian

aspirasi khususnya dalam hal seni dan budaya yang cukup terkenal di desa solam raya sejak dulu sudah di berikan kesempatan yang sama kepada setiap suku dan kelompok masyarakat untuk dapat melaksanakan proses adat isitiadat dalam berbagai momen. Potensi yang dapat memberikan nilai positif kepada masyarakat tersebut di lindungi oleh pemerintah desa karena dapat menciptakan berbagai kreatifitas dan pendidikan budaya bagi generasi muda oleh karenanya pelestarian seni budaya tidak saja didukung oleh pemerintah akan tetapi juga didukung oleh BPD sebagai perwakilan masyarakat.

Selanjutnya hasil wawancara dengan Ketua Kelompok Seni Budaya di Desa Solam Raya Kecamatan Sungai Tebelian mengatakan dalam mejalankan aktivitas kebudayaan di desa solam raya ini sudah berlangsung lama dan sudah memperoleh ijin dari pemerintah desa, hal ini tidak saja pada kesenian daerah akan tetapi pada budaya daerah lainnya yang biasa digunakan masyarakat juga sudah disampaikan kepada pemerintah desa untuk tetap dijaga dan dijalankan oleh masyarakat. Selain itu dikatakan oleh ketua kelompok seni budaya dalam berbagai acara seni budaya daerah sering ditampilkan sebagai upaya memperkenalkan kebudayaan daerah dan hal ini juga merupakan keinginan masyarakat pada awalnya yang ingin memberikan nilai positif bagi terciptanya pembangunan budaya yang berkelanjutan.

Berlandaskan hasil wawancara yang terhimpun dari Ketua Seni Budaya Desa Solam Raya dapat dijelaskan bahwa terdapat kepuasan dari masyarakat dalam mengapresiasikan kesenian tradisional dan juga adat istiadat di desa Solam Raya hal ini karena dukungan pemerintah desa dan juga BPD dalam bentuk kebijakan. seni budaya di Desa Solam Raya sering dijadikan pengisi acara dalam setiap momen resmi yang dilakukan di Desa dan Kecamatan sebagai bentuk memperkenalkan keharmonisan dan keragaman kebudayaan di desa Solam Raya. Bentuk dukungan pemerintah diharapkan dapat menjamin keberlangsungan dari kesenian dan adat budaya sehingga nilai positif yang menjadi tujuan utama yaitu melestarikan dan memperkenalkan kepada generasi muda dengan mudah dapat terlaksana. keberhasilan pemerintah desa Solam Raya dalam mengangkat dan melestarikan seni dan budaya juga menjadi potensi daerah yang terus didukung secara kooperatif oleh BPD sebagai bagian dari wadah menyampaikan aspirasi masyarakat setempat.

Dari hasil observasi tersebut dapat dijelaskan bahwa sistem penyampaian atau 
penyaluran aspirasi masyarakat kepada pemerintah melalui BPD sudah berjalan sesuai dengan keharusan yang diamanatkan peraturan kepada BPD demikian juga sebaliknya BPD Solan Raya telah menjalankan perannya sebagai perwakilan masyarakat yang menampung dan menyampaikan perihal usulan masyarakat ke pemerintah desa.

Proses pembangunan menjadi tanggungjawab bersama seluruh elemen pemerintah dengan melibatkan unsur lainnya seperti sektor swasta atau kelompokkelompok masyarakat yang tergabung dalam aktivitas tertentu atau kegiatan positif lainnya yang dapat berpengaruh pada pola kehidupan masyarakat yang baik dan sejahtera. Berdasarkan hal tersebut maka pembangunan harus dilandasi oleh rasa kebersamaan, untuk membangun kebersamaan dalam pembangunan diperlukan adanya koordinasi yang berjalan dengan baik sesuai dengan ranah kewenangan masing-masing agar tidak terjadi perbedaan pandangan dalam menggerakan potensi yang ada di masyarakat.

\section{Koordinasi Dalam Penyerapan Aspirasi Masyarakat}

Berdasarkan hasil wawancara dengan Kepala Desa Solam Raya diperoleh informasi bahwa dalam menyelenggarakan pembangunan agar tercipta kebersamaan baik antara pemerintah desa dengan BPD memerlukan adanya koordinasi yang baik, tujuan dari keberadaan pemerintahan desa dan BPD pada dasarnya sama-sama ingin mewujudkan adanya suatu pembangunan yang terarah bagi masyarakat. Sedangkan dalam setiap penyerapan aspirasi pada masyarakat BPD memiliki tatacara dan sistematika tersendiri yang sesuai dengan kewenangan BPD namun demikian hal-hal tersebuttentunya harus dikoordinasikan kepada pemerintah desa agar tidak memiliki perbedaan dalam merealisasikan pembangunan.

Selanjutnya menurut Kepala Desa bahwa sistem koordinasi tidak saja harus dilakukan dengan pemerintah desa akan tetapi juga di dalam internal BPD sebagai perwakilan masyarakat di pemerintahan desa. Sistem koordinasi yang dilakukan selama ini sudah berjalan dengan baik dimana secara bersama-sama pemerintah desa dan BPD merencanakan program pembangunan dan juga bersama melaksanakan pembangunan yang sudah berjalan dan untuk membangun suatu kerjsama yang efektif dianatara anggota BPD serta pemerintah di desa maupun dusun dilakukan rapat-rapat koordinasi.

Berlandaskan hasil wawancara yang terhimpun dari Kepala Desa dapat dijelaskan bahwa untuk membangun kebersamaan bentuk koordinasi di lakukan dengan bPD yang menjalankan fungsi pengawasan pada 
pemerintah desa. Demikian juga dengan pemerintahan desa sering melakukan koordinasi dengan BPD melalui rapat-rapat koordinasi untuk mendengarkan berbagai pandangan dan pendapat dalam mejalankan pembangunan desa khususnya desa Solam Raya. Sehubungan dengan pelestarian kesenian daerah atau seni budaya daerah yang sudah berjalan saat ini juga dilakukan koordinasi dalam rangka meningkatkan kinerja kelompok seni budaya agar terus mengembangkan kelompoknya sehingga dapat dijadikan salah satu ciri khas bagi masyarakat di Desa Solam Raya.

Berikutnya hasil wawancara dengan Ketua BPD Solam Raya menjelaskan bahwa walaupun BPD sudah memiliki fungsi dan tugasnya yang tertuang dalam berbagai peraturan perundang-undangan namun tetap melakukan koordinasi dengan pemerintah desa, hal ini dilakukan karena fungsi BPD dalam meyerap aspirasi masyarakat harus ditindak lanjuti kepada pemerintah desa oleh karenanya melalui koordinasi akan lebih memudahkan sistem kerja anggota BPD. Selain itu dijelaskan oleh Ketua BPD bahwa koordinasi juga dilakukan di dalam internal anggota BPD dan juga dengan tokoh-tokoh masyarakat serta ketua kelompok seni dan budaya agar diperoleh suatu gambaran yang lengkap sesungguhnya keberadaan seni dan budaya yang telah diaspirasikan masyarakat kepada BPD.

Lebih lanjut menurut Ketua BPD Solam Raya selain melaksanakan fungsi pengawasan dan juga penetapan peraturan desa, BPD juga harus dapat menjalankan perannya di dalam masyarakat yaitu menyerap setiap aspirasi yang menjadi keinginan masyarakat. Salah satu aspirasi masyarakat yang sudah di rencanakan oleh BPD untuk di ajukan kedalam rpat BPD yaitu meningkatkan kualitas kelompok seni dan budaya yang sudah ada di masyarakat desa Solam Raya. Untuk dapat mewujudkannya sudah pasti diperlukan koordinasi lebih lanjut dengan pemerintah desa, hal ini dilakukan agar terdapat pemahaman dan informasi yang jelas arah serta tujuan dari peningkatan kualitas seni dan budaya daerah agar dapat menjadi salah satu andalan desa Solam Raya.

Berdasarkan hasil wawancara yang telah diperoleh dari Ketua BPD dapat dipahami bahwa BPD dan pemerintah desa memiliki tugas pokok dan fungsi yang berbeda sehingga program kerja yang direncanakan juga berbeda namun untuk tetap meyatukan tujuan BPD dan pemerintah desa sama-sama memahami peran masing-masing. Koordinasi dimaksudkan untuk mengetahui secara jelas dan lengkap arah dan tujuan pembangunan yang direncanakan pada tahun anggaran 
berikutnya. Selain itu koordinasi yang paling penting yaitu melalui rapat dengan pemerintah desa sebagai bagian dari sistem pengawasan BPD kepada pemerintahan desa.

Dalam konteks pelestarian seni dan budaya pemerintah desa dan BPD satu tujuan yaitu ingin membangun suatu kebersamaan dalam menyelesaikan dan meningkatkan kualitas sumber daya manusia agar seni dan budaya di Desa Solam Raya dapat menjadi suatu potensi bagi masyarakatnya.

Lebih lanjut hasil wawancara dengan Anggota BPD mengatakan bahwa untuk melaksanakan peran sebagai perwakilan masyarakat koordinasi merupakan sistem yang paling efektif sehingga seluruh anggota BPD tidak mengalami hambatan dalam menyerap aspirasi masyarakat. Koordinasi yang dilakukan pada tokoh masyarakat dapat dilakukan setiap kali melaksanakan rapat selanjutnya dilakukan juga koordinasi dengan seluruh BPD dalam rapat resmi sesuai dengan keperluannya. Adapun sistem koordinasi pada dasarnya untuk membangun kerjasama antara semua unsur yang bertanggungjawab dalam pembangunan desa. Berkaitan dengan peningkatan dan pelestarian kesenian daerah dan juga budaya daerah sudah jelas harus dikoordinasikan dengan pihak pemerintah desa sebagai pemangku wilayah agar dapat mengetahui dengan baik kondisi sosial budaya masyarakatnya.

Selain itu menurut Anggota BPD dalam hasil wawancaranya di peroleh hasil yaitu dengan melakukan koordinasi selama ini sangat efektif dan mudah dalam membangun kebersamaan demikian juga dengan masyarakatnya melalui koordinasi tersebut akan lebih memudahkan sistem penyerapan aspirasi serta menyampaikan aspirasi yang akan menjadi bagian dari arah pembangunan masyarakat di desa Solam Raya, sejak dulu kesenian tradisional masyarakat seperti kelompok kuda lumping, kelompok wayang dan juga seni tari dari kelompok masyarakat Dayak sudah dijadikan bagian dari pembangunan masyarakat berbasis seni budaya. bahkan dianjurkan kepada masyarakat untuk dapat terus mempertahankan dan meningkatkan menjadi kesenian yang dapat mendatangkan hasil ekonomi bagi pelakunya. Berdasarkan hasil wawancara yang telah terhimpun dari anggota BPD dapat dipahami bahwa dalam rangka menjalankan peran sebagai perwakilan masyarakat hasil dari penyampaian aspirasi dikoordinasikan kepada ketua dan anggota BPD dalam rapat BPD yang selanjutnya menjadi salah satu usulan yang disampaikan BPD kepada pemerintah desa. Sistem koordinasi juga dilakukan dengan unsur pemerintah desa dalam rangka memberikan pemahaman 
bahwa kesenian daerah dapat dijadikan suatu bentuk pengembangan manusia dalam konteks seni dan budaya oleh karena harus ada perhatian agar tujuannya menjadi nyata dan semakin bermanfaat bagi masyarakat. Upaya membangun koordinasi pada semua pihak juga dilakukan oleh BPD agar terdapat kesamaan dan tidak adanya perbedaan dalam mengarahkan tujuan dari pembangunan itu sendiri. pemahaman terhadap keberadaan seni dan budaya harus dilihat sebagai potensi dan untuk itu diperlukan keinginan bersama memberikan perhatian pada kesenian daerah.

Selanjutnya hasil wawancara dengan Ketua kelompok seni budaya di Desa Solam Raya diperoleh informasi yaitu pelaksanaan fungsi koordinasi dengan pemerintah desa dan juga BPD dilakukan kepada masyarakat tentunya sudah maksimal demikian juga dengan uapaya mengembangkan kesenian daerah selama ini. Menurut ketua kelompok seni dan budaya bahwa untuk dapat mengembangkan seni dan budaya pada dasrnya tidaklah mudah diperlukan kemauan yang tinggi dari semua pihak karena secara sekilas keberadaan seni dan budaya belumlah dapat diandalkan sebagai bagian dari upaya meningkatkan pendapatan asli desa sehingga sistem koordinasi perlu dilakukan secara berkelanjutan dengan semua masyarakat agar sama-sama dapat memahami nilai-nilai yang dapat di peroleh dari pengembangan kesenian daerah.

Selanjutnya menurut ketua kelompok seni dan budaya bahwa semuanya dapat memahami bahwa pendanaan merupakan salah satu aspek yang diperlukan dalam mendukung terselenggaranya kesenian yang berkualitas dan untuk itu diperlukan prosesproses yang bertahap sehingga diperlukan kesabaran bagi pelaksanan kesenian atau penggiat kesenian namun demikain semangat untuk terus melakukan koordinasi harus terus dijaga karena kesenian daerah bagaimanapun sanagt tergantung dengan pemerintah dalam menjalankannya.

Lebih lanjut di jelaskan oleh Ketua kelompok seni dan budaya bahwa untuk meningkatkan dan mengembangkan kesenian daerah tidak dapat dipungkiri harus ada koordinasi yang efektif pada semua pihak selain pada pemerintah desa koordinasi juga harus dibangun dengan sektor swasta dan juga pemerintah kecamatan serta pemerintah Kabupaten karena kesenian suatu daerah adalah salah satu modal bagi daerah yang dapat dikembangkan menjadi potensi besar untuk kemajuan daerah tersebut, untuk itu melalui BPD diharapkan koordinasi dengan semua pihak dapat berjalan dengan baik dan untuk itu upaya yang sudah disampaikan kepada BPD adalah memberikan informasi 
kepada semua pihak tersebut agar diperoleh suatu keyakinan akan besarnya potensi yang dapat dimanfaatkan secara berkelanjutan di Desa Solam Raya.

Berlandaskan hasil wawancara yang telah terhimpun dapat dijelaskan bahwa harapan masyarakat terhadap lembaga perwakilan masyarakat yaitu BPD sebagai jembatan yang dapat menyampaikan aspirasi masyarakat pada tingkat pemerintahan yang lebih tinggi, hal ini mengingat BPD merupakan bagian dari sistem pelaksanaa pemerintahan yang paling dekat dengan masyarakat dan yang paling mengetahui berbagai keinginan dan tujuan yang dikehendaki masyarakat. Koordinasi BPD dengan semua pihak dalam melestarikan kesenian daerah menjadi salah satu tanggungjawab yang hingga saat ini masih terus dilakukan melalui berbagai bentuk koordinasi kepada banyak pihak termasuk kepada dunia usaha yang ada di desa Solam Raya.

Selanjutnya hasil observasi menunjukan adanya dokumen-dokumen hasil rapat koordinasi antara pemerintah desa dan BPD dalam membahas berbagai bentuk arah pembangunan yang akan dilaksanakan pada setiap tahun anggaran, selain itu terlihat BPD melakukan rapat-rapat koordinasi di dalam internal BPD yaitu pada saat merencanakan program kerja, pelaksanaan pengawasan dan juga pada saat menyusun rencana yang diusulkan pada musrenbang desa dimana terdapat poin yang berkenaan dengan usulan meningkatkan keberadaan kelompok seni dan budaya di desa Solam Raya. Koordinasi juga terlihat dari seluruh anggota BPD dengan masyarakat di beberapa dusun dalam bentuk rapat bersama mengajukan usulan rencana pembangunan yang menjadi prioritas masyarakat.

\section{Partisipasi Masyarakat Dalam Meyampaikan Aspirasi Kepada BPD}

Berdasarkan hasil wawancara dengan Kepala Desa Solam Raya Kecamatan Sungai Tebelian diperoleh informasi yaitu dalam setiap penyusunan APBDes yaitu pada saat Musrenbag desa masyarakat sudah terlibat terutama tokoh-tokoh masyarakat dan juga tokoh agama serta ketua kelompok pemuda, ketua kelompok seni budaya. Antusias mengikuti Musrenbang desa juga tampak pada masyarakat dimana prosesproses pembahasan yang menjadi rencana pembangunan juga datangnya dari masyarakat setempat. Dinamika ini sejak otonomi daerah mulai dirasakan karena salah satu syarat dalam mengajukan usul pembangunan yaitu adanya keterlibatan masyarakay. Oleh karena itu untuk membangun partisipasi pemerintah desa mensosialisasikan manfaat dari adanya keterlibatan masyarakat. 
104 Perahu, Volume 5 Nomor 2, September 2017, Hlm 93-106

Lebih lanjut menurut Kepala

Desa diperoleh informasi yaitu dalam melangsungkan kegiatan seni budaya yang menjadi keinginan masyarakat sudah diupayakan beberapa hal yaitu alokasi dana melalui ADD kepada kelompok pemuda dan juga kelompok seni budaya yang sifatnya berkelanjutan. Sedangkan untuk menambah motivasi dalam melestarikan kesenian diharapkan kepada kelompok kesenian untuk dapat langsung mendatangi instansi yang berwenang pada tingkat kabupaten. Dukungan pemerintah desa dalam bentuk kebijakan juga sudah dilakukan karena merupakan usulan dari BPD yang sangat mengetahu dan memahami aspirasi masyarakat tersebut.

Berangkat dari hasil wawancara yang telah terhimpun dari Kepala Desa dapat diasumsikan bahwa keterlibatan masyarakat cukup tinggi dan bahkan meningkat terutama sejak pemerintahan desa diberikan hak mengatur pembangunan sendiri kemudian dalam menyampaikan aspirasinya kepada BPD juga sudah meningkat karena BPD sudah menjadi lembaga yang berbeda dengan pada saat sebelumnya BPD merupakan bagian dari penyelenggaraan pemerintahan desa. hal ini tentunya secara administratif membedakan kedudukan BPD yang utmanya mengawasi dan menyalurkan aspirasi masyarakat.

Selanjutnya berdasarkan hasil wawancara dengan Ketua BPD Desa Solam Raya Kecamatan Sungai Tebelian diperoleh informasi bahwa pada saat ini dengan mengacu pada Undang-Undang nomor 6 tahun 2014 BPD lebih leluasa menggunakan perannya dalam mendekatkan diri dengan masyarakat karena harus memperolehaspirasi dari masyarakay untuk bahan yang akan diajukan dalam Musrenbangdesa dan juga setelah ditetapkan menjadi APBDes.

Berikutnya menurut hasil wawancara denganKetuaBPDdikatakanadiantaraaspirasi masyarakay yang paling dominan disampaikan yaitu sehubungan dengan kesenian dan budaya dimana kebudayaan masyarakay selama ini belum ada suatu kekuatan hukum secara jelas untuk mengapresiasikannya, sehingga bagi masyarakat desa diperlukan adanya kepastian dalam menyikapi setiap kondisi kebijakan yang belum tentu dapat memihak pada bidang kebudayaan. Dalam hal ini BPD telah mengusulkan kepada pemerintah desa untuk merencanakan adanya suatu kebijakan yang secara hukum menjamin adanya kebebasan dalam menjalankan kesenian dan budaya pada suatu daerah tertentu.

Berlandasakan pada hasil wawancara yang terhimpun dari Ketua BPD dapat dideskripsikan bahwa masyarakat sangat memahami bahwa peran budaya dapat membantu menjaga keaslian masyarakat 
dengan tidak menolak berbagai kemajuan yang

terjadi, kendala yang dihadapai yaitu belum adanya jaminan kebijakan yang mendorong lahirnya kebebasan dalam mengaktualisasikan kedalam bentuk kesenian yang sedapat mungkin mendatangkan hasil bagi pemerintah dan masyaakat. Dengan keberdaan BPD keinginan tersebut sudah menuju pada arah yang cukup jelas dimana paling tidak bagi masyarakat adat perlu adanya kebijakan pada tataran pemerintah desa. Sehingga di Desa Solam Raya hal ini sudah menjadi bagian dari sistem pembangunan berkelanjutan atau menjadi program kerja berkelanjutan sesuai dengan adanya anggaran yang dapat dibagikan untuk keperluan tersebut.

Selanjutnya hasil wawancara dengan Ketua Kelompok Seni Budaya di Desa Solam Raya Kecamatan Sungai Tebelian diperoleh informasi bahwa kesenian daerah yang sudah terbentuk dalam kelompok-kelompok selama ini sudah sering ditampilkan dalam berbagai acara khususnya disekitar desa Solam Raya sehingga muncul keinginan untuk dapat diorganisir dengan resmi dan dengan demikian akan dapat memiliki akses dalam mengusahakan bantuan kepaa pemerintah dan pihak swasta. Dari hasil pengalaman para penggiat kesenian menurut ketua kelompok seni selain dapat menghasilkan nilai ekonomis juga sebagai bagian dari membangun kebersamaan dan keharmonisan karena saat ini bagi kelompok-kelompok kesenian akan muncul adanya ancaman bagi budaya seandainya tidak di berikan ruang dan landasan kebijakan yang pasti.

Berikutnya dituturkan juga oleh ketua kelompok kesenian daerah di Desa Solam Raya bahwa sejak lama keinginan untuk memperoleh perhatian dan dukungan pemerintah sudah ada namun untuk menuju kearah tersebut masih terbentur berbagai hal seperti dukungan pemerintah desa dan BPD. Masyarakat tidaklah dapat bergerak sendiri tanpa adanya dukungan dari pemerintah desa karena proses pembinaan tentunya harus dimulai dari bawah terlebih dahulu.

Berlandasakan pada hasil-hasil wawancara yang terhimpun dari Ketua Kelompok Seni Budaya di Desa Solam Raya dapat diasumsikan bahwa inspirasi masyarakat dalam melestarikan kebudayaan daerah dimulai dari pesatnya perubahan zaman yang semakin menggeser peran budaya dalam kehidupan masyarakat, selain itu perhatian pemerintahlebih terpokus pada pembangunan fisik atau infrastruktur sehingga belum dapat menjamin kesejahteraan masyarakat. Dalam rea otonomi daerah merupakan kesempatan bagi masyarakat untuk dapat meningkatkan peran kebudayaan di daerah dalam berbagai kesempatan dan untuk itu diperlukan adanya 
dukungan pemerintah desa sebagai landasan

utama dalam meningkatkan pembinaan kepada generasi berikutnya bahwa kebudayaan dapat menjadi wadah dalam menyampikan berbagai pesan kepada masyarakat dan generasi muda pada masa sekarang ini. Potensi budaya yang ada dapat saja memberikan dampak positif bagi pemerintah desa namun untuk mencapai kearah tersebut tentunya memerlukan waktu da kerjasama yang baik.

\section{DAFTAR PUSTAKA}

Abdullah, Rozali 2005Pelaksanaan Otonomi Luas dengan Pemilihan Kepala Daerah Secara Langsung, Jakarta : RajaGrafindo Persada,.

Afiffudin. 2010. Pengantar Administrasi Pembangunan (Konsep, Teori dan Implikasinya di Era Reformasi). Bandung : Alfabeta.

Arikunto, S. 2007. Prosedur Penelitian. Jakarta : Renika Cipta

Gie, The Liang. 2002, Analisis Administrasi Dan Manajemen, Gramedia, Jakarta.

Handayaningrat, Soewarno, 1991, Administrasi Pemerintahan Dalam Pembangunan Nasional, Jakarta : CV. Haji Mas Agung.

Hetifah, Sj Sumarto. 2003. Inovasi, Partisipasi, dan Good Governance. Yayasan Obor Indonesia. Jakarta.

Lugiarti, Eppy. 2004. Peningkatan Partisipasi Masyarakat dalam Proses Perencanaan Program Pengembangan Masyarakat di Komunitas Desa Cijayanti. Tesis. Pascasarjana, IPB.

Ndraha, Taliziduhu (1990). Pembangunan Masyarakat, Mempersiapkan Masyarakat Tinggal landas. Jakarta : PT. Rineka Cipta.

Melisa Fitra,Melisa Fitra, (2009), Peranan Badan Permusyawaratan Desa dalam Penyelenggaraan Pemerintahan di
Desa." (Skripsi Sarjana Ilmu Politik dan Ilmu Pemerintahan, ) dalam

Notoatmodjo, Soekidjo, 2003, Pengembangan Sumber Daya Manusia, PT Rineka Cipta,. Jakarta.

Siagian.S P. 2003,Teori dan Praktek Kepemimpinan, cet.Kelima Jakarta:Rineka Cipta.

Slamet, Y. 2003. Pembangunan Masyarakat Berwawasan Partisipasi. Surakarta: Sebelas Maret University Press.

Solekhan, Moch.. 2012. Penyelenggaraan Pemerintahan Desa. Malang: Setara Press.

Soetomo., 2006, Strategi-Strategi Pembangunan Masyarakat. Yogyakarta: Pustaka. Pelajar.

Soekanto, Soerjono (2002). Sosiologi Suatu Pengantar. Jakarta : Raja Grafindo Persada.

Sumardjo dan Saharudin, 2003. Metodemetode Partisipatif dalam Pengembangan Masyarakat. Jurusan Ilmu-ilmu Sosial Ekonomi Faperta IPB

Suharto, Edi, 2005, Analisis Kebijakan Publik: Panduan Praktis Mengkaji Masalah dan Kebijakan Sosial, Cetakan Kedua. Edisi Revisi. Bandung: ALFABETA.

Syamsi, Ibnu 1986 Partisipasi, Komunikasi, Persuasi dan Displin dalam Pembangunan Jakarta: Rineka Cipta.

Undang-Undang Nomor 6 tahun 2014 Tentang Desa

Wijaya, HAW. 2004. Penyelenggaran Otonomi Di Indonesia, Dalam Rangka Sosialisasi Undang- Undang No. 32 Tahun tentang Pemerintahan Daerah. 